\title{
EFFECT OF POSTOPERATIVE RADIATION ON THE INCORPORATION OF TIBIAL BONE GRAFTS IN THE RABBIT
}

\author{
G. De SANTIS, J. F. WILliaMS, E. DVIR, B. McC. O'BRIEN, J. V. HURLEY, I. GOLDBERG
}

From St. Vincent's Hospital, Melbourne

\begin{abstract}
A dose of $48 \mathrm{~Gy}$ of $\mathrm{X}$-irradiation given over two to five weeks after grafting caused no significant delay in the rate of healing and only a small and statistically non-significant decrease in the torsional strength of the graft-bone junction of either vascularised or non-vascularised bone grafts of the tibiae of rabbits. Healing was faster and the union between the graft and adjacent bone developed torsional strength significantly more rapidly with vascularised than with non-vascularised grafts.

These findings suggest that postoperative radiotherapy is unlikely to have a significantly deleterious effect on the healing of bone grafts used to repair defects produced by excision of malignant bone tumours.
\end{abstract}

The traditional treatment for malignant tumours of bone is amputation. Such treatment has now been replaced by wide local excision and adjuvant radiotherapy or chemotherapy. Wide local excision of a tumour leaves a large bony defect, which is usually repaired with either a vascularised or non-vascularised bone graft.

Little has been published on the effects of radiotherapy on the healing of bone grafts. We now report a study in rabbits of the effect of postoperative radiotherapy on the healing of both vascularised and non-vascularised grafts of the tibia. Healing was assessed by the mechanical strength of the graft at nine and 17 weeks after operation, and by radiological and histological examination.

\section{MATERIALS AND METHODS}

Study design. A total of 80 outbred rabbits of New Zealand strain were divided into four groups of 20 : group $\mathrm{A}$, had a vascularised graft with $48 \mathrm{~Gy}$ radiation; group $\mathrm{B}$, a free non-vascularised graft with $48 \mathrm{~Gy}$ radiation;

G. De Santis, MD, Research Fellow

E. Dvir, MD, Research Fellow

B. McC. O'Brien, $C M G$, MD, MS, BSc, FRCS, FRACS, FACS, Director, Microsurgery Research Centre, and Senior Plastic Surgeon J. V. Hurley, MD, PhD, FRCPath, FRACP, FRCPA, Consultant Pathologist

Microsurgery Research Centre, St. Vincent's Hospital, 41 Victoria Parade, Fitzroy 3065, Victoria, Australia.

J. F. Williams, PhD, Reader in Mechanical Engineering University of Melbourne, Melbourne, Australia.

I. Goldberg, MD, Former Research Fellow

Orthopaedic Department, Beilinson Hospital, Petah-Tikva, Israel.

Correspondence should be sent to Mr B. McC. O'Brien.

(C) 1990 British Editorial Society of Bone and Joint Surgery 0301-620X/90/2048 $\$ 2.00$

J Bone Joint Surg [Br] 1990; 72-B:309-11. group C, a vascularised graft without radiation; and group D, a free non-vascularised graft without radiation.

Ten rabbits from each group were killed nine weeks after operation (four weeks after radiotherapy) and the remaining 10 rabbits in each group were killed 17 weeks after operation (12 weeks after grafting).

Surgical technique. Operations were by sterile technique under general anaesthesia. A graft of a uniform length of $5.5 \mathrm{~cm}$ (average length of tibia $10 \mathrm{~cm}$ ) was cut through the full thickness of the tibia, the upper end of the graft being located just distal to the tibial tuberosity.

Vascularised grafts. The graft was isolated on vascular pedicles arising from the anterior and posterior tibial arteries, taking care to leave intact the blood supply to the periosteum and all muscular attachments. The graft was replaced in position and secured by an endomedullary pin. If the graft showed a tendency to rotate, a thinner wire was placed across the upper osteotomy site.

Non-vascularised grafts. The graft was dissected subperiosteally and removed completely from its blood supply. It was then replaced in its bed and secured in position in the same manner as the vascularised grafts.

Radiotherapy. Irradiation was begun two weeks after operation at a dosage of $5.33 \mathrm{~Gy}$ three times a week for three weeks - a total dose of $48 \mathrm{~Gy}$. Radiation rate was $0.6 \mathrm{~Gy} / \mathrm{min}$ with a half value layer of $2.5 \mathrm{~mm}$ of copper.

Assessment. Anteroposterior and oblique radiographs were made every two weeks from operation to killing in five animals from each group.

Torsional strength. Immediately after killing, the tibia was dissected free from surrounding tissue and immersed in normal saline. Within six hours of removal the proximal and distal ends of the tibia were cemented into box-like grips with 'Vertex' quick setting dental compound, and the strength of the graft-bone union tested in 
simple torsion with a screw-driven 'Instron 1114 Universal Testing Machine' at a quasi-static loading rate of $36^{\circ} \%$ min. The test used was designed to provide comparative values of the effects of vascularisation and irradiation on the graft-bone union rather than absolute values (Burstein and Frankel 1971).

Histological examination. After mechanical tests had been completed specimens from three of the non-fractured ends of the graft in each group were fixed in formolsaline, decalcified, and embedded in paraffin. Sections were cut and stained by standard methods.

\section{RESULTS}

Torsional strength. Torsional strength tests were done on 69 grafts, 11 animals being excluded because of infection of the graft site. Table I shows the torsional strength of the graft-bone union in each animal tested. At both nine and 17 weeks after operation the mean torsional strength of graft-bone union of vascularised grafts was more than double that of non-vascularised grafts in both control and irradiated animals. Irradiation caused a slight decrease in the mean torsional strength of graft-bone union of both vascularised and non-vascularised grafts.

Irrespective of vascularisation or irradiation there was very little increase in the strength of graft-bone union between nine and 17 weeks after operation. For statistical comparisons the data were analysed as a threefactor, fixed effect analysis of variance with unequal cells (Table II). The only significant effect was that of vascularisation (strength with vascularised versus nonvascularised grafts $(p<0.001)$. The slight decrease in strength of grafts following irradiation was not statistically significant, nor did the strength of grafts differ significantly at nine and 17 weeks after operation.

Radiology. In vascularised grafts four weeks after operation, callus was visible on each side of the osteotomy site; by two months union was almost complete and by three to four months complete union and evidence of remodelling of the callus were apparent. The progress of healing was similar in control and irradiated animals, but irradiation seemed to increase the time between operation and complete union by about two weeks.

In non-vascularised grafts, healing was slower than in vascularised grafts. Three to four months after operation seven of 10 grafts had united and showed signs of early remodelling. However, one of five control grafts and two of five irradiated grafts had not united by the time the animals were killed. The presence of radiation osteitis was not evident radiologically in any animal examined.

Histology. The appearances were similar in control and irradiated animals; no histological changes due to irradiation could be identified.

In all vascularised grafts the graft had the appearance of normal living bone, but at nine weeks after operation the osteotomy site was still visible, bridged on either side by mature callus. At 17 weeks after operation
Table I. The effect of irradiation on the torsional strength of union between graft and host bone of vascularised and nonvascularised tibial grafts in rabbits 9 and 17 weeks after operation

\begin{tabular}{|c|c|c|c|}
\hline \multirow[b]{2}{*}{ Type of graft } & \multirow{2}{*}{$\begin{array}{l}\text { Time after } \\
\text { operation } \\
\text { (weeks) }\end{array}$} & \multicolumn{2}{|c|}{$\begin{array}{l}\text { Torsional strength } \\
(\mathrm{kg} / \mathrm{cm})\end{array}$} \\
\hline & & Control & Irradiated \\
\hline \multirow[t]{4}{*}{ Vascularised } & 9 & $\begin{array}{r}10.9 \\
8.2 \\
18.5 \\
11.6 \\
18.2 \\
7.9 \\
13.0\end{array}$ & $\begin{array}{r}5.2 \\
12.0 \\
10.7 \\
8.6 \\
13.9 \\
4.7 \\
4.5\end{array}$ \\
\hline & Mean & 12.61 & 8.94 \\
\hline & 17 & $\begin{array}{r}19.5 \\
22.0 \\
12.5 \\
14.9 \\
16.8 \\
7.5 \\
0^{*} \\
7.1 \\
11.0\end{array}$ & $\begin{array}{r}5.4 \\
14.2 \\
10.8 \\
13.3 \\
15.5 \\
6.4 \\
14.4 \\
14.8 \\
9.3 \\
6.8\end{array}$ \\
\hline & Mean & 12.37 & 11.09 \\
\hline \multirow[t]{4}{*}{ Non-vascularised } & 9 & $\begin{array}{l}0^{*} \\
0^{*} \\
8.25 \\
0^{*} \\
8.0 \\
6.75 \\
4.0 \\
0^{*} \\
17.2\end{array}$ & $\begin{array}{c}0^{*} \\
0^{*} \\
10.9 \\
0^{*} \\
2.3 \\
0^{*} \\
11.0 \\
- \\
-\end{array}$ \\
\hline & Mean & 4.43 & 3.02 \\
\hline & 17 & $\begin{array}{r}20.6 \\
1.0 \\
6.6 \\
6.0 \\
9.9 \\
10.5 \\
3.0 \\
9.1 \\
12.0 \\
5.1 \\
3.6\end{array}$ & $\begin{array}{c}6.8 \\
10.0 \\
0^{*} \\
3.1 \\
\\
0^{*} \\
7.5 \\
9.7\end{array}$ \\
\hline & Mean & 7.04 & 5.30 \\
\hline
\end{tabular}

*non-union

Table II. The effect of vascularisation, irradiation and time, each averaged for the other factors, on the torsional strength of tibial bone grafts in rabbits

\begin{tabular}{|c|c|c|}
\hline Factor & $\begin{array}{l}\text { Mean strength } \\
(\mathbf{k g} / \mathbf{c m})\end{array}$ & $\begin{array}{l}\text { Significance of } \\
\text { difference }\end{array}$ \\
\hline $\begin{array}{l}\text { Vascularisat } \\
\text { With } \\
\text { Without }\end{array}$ & $\begin{array}{r}11.253 \\
4.948\end{array}$ & $\mathrm{p}<0.001$ \\
\hline $\begin{array}{l}\text { Irradiation } \\
\text { With } \\
\text { Without }\end{array}$ & $\begin{array}{l}7.094 \\
9.112\end{array}$ & NS \\
\hline $\begin{array}{l}\text { Time } \\
9 \text { weeks } \\
17 \text { weeks }\end{array}$ & $\begin{array}{l}7.253 \\
8.948\end{array}$ & NS \\
\hline
\end{tabular}


no gap remained at the site of the osteotomy, which could be identified only by an irregular pattern of trabeculae within the bone.

In non-vascularised grafts at both nine and 17 weeks after operation the degree of repopulation by osteocytes of bone lacunae within the graft varied widely. In some grafts almost half the lacunae contained osteocytes; in others all lacunae were empty. Nine weeks after operation the fracture line was still clearly visible with mature callus present around it. At 17 weeks the fracture in some animals was well healed by mature external callus. In other specimens, although much callus was present, no bony union had occurred across the fracture site.

\section{DISCUSSION}

The dose and mode of administration of irradiation was chosen to be close to that likely to be used clinically after local excision of a bone tumour. The results of the torsional strength tests indicate that, with both vascularised and non-vascularised grafts, this level of irradiation produces only a slight decrease in the torsional strength of bone-graft union nine and 17 weeks after grafting. In neither type of graft was the decrease significant, and radiological and histological studies provided no evidence of significant impairment of healing.

The present findings are in accord with the few other reports on the effects of radiotherapy on the healing of bone grafts. In histological and radio-isotopic studies of non-vascularised bone grafts in rats (Elves and Lynette 1975; Elves 1976) showed that irradiation caused only temporary and reversible inhibition of bone healing. In eight cases of bone tumour treated by total excision, nonvascularised bone grafting and postoperative radiotherapy, Roy-Camille et al (1981) found that doses up to 4000 rads caused no delay in graft consolidation, but that a dose of 6000 rads jeopardised the healing of the graft.

The available evidence suggests that the use of moderate doses of irradiation shortly after insertion of a bone graft will cause no clinically significant impairment of the healing or strength of either a vascularised or nonvascularised graft.

Advocates of the use of vascularised bone grafts have claimed that an intact vascular pedicle decreases the time to bone union without any decrease in graft strength (Weiland 1981). However, experimental evidence is conflicting. Dell, Burchardt and Glowczewsie
(1985) and Weiland, Phillips and Randolph (1984) reported no significant difference in the strength and rate of healing of vascularised and non-vascularised grafts, whereas Moore et al (1984) claimed that vascularised grafts inserted into the ulna of dogs were over $200 \%$ stronger than conventional grafts.

Our findings support Moore et al, and indicate that vascularised grafts both heal more rapidly and develop strength faster than non-vascularised grafts. Precise assessment of the rate of healing in histological sections is difficult, so the most reliable index of healing is the frequency of non-union at different stages after operation. Of 33 vascularised grafts, with or without irradiation, only one had not healed by nine weeks, and at 17 weeks all grafts were firmly united. With non-vascularised grafts, nine of 18 had not united by nine weeks and two of 18 were still un-united at 17 weeks.

With respect to tensile strength, in both control and irradiated animals at both nine and 17 weeks, the strength of vascularised grafts was more than double that of nonvascularised grafts. Statistically the differences are highly significant. In this experimental system there can be no doubt of the superiority of vascularised grafts.

Thanks are due to Dr G. Hodgson of Peter McCallum Clinic and the Radiological Department, St. Vincent's Hospital for X-ray facilities, and to Michael Hickey for assistance in the histological studies. The work was supported by a grant from St. Vincent's Hospital.

No benefits in any form have been received or will be received from a commercial party related directly or indirectly to the subject of this article.

\section{REFERENCES}

Burstein AH, Frankel VH. A standard test for laboratory animal bone J Biomech 1971; 4:155-8.

Dell PC, Burchardt H, Glowczewsie FP Jr. A roentgenographic, biomechanical and histological evaluation of vascularized and non-vascularized segmental fibular canine autografts. $J$ Bone Joint Surg $[\mathrm{Am}] 1985 ; 67-\mathrm{A}: 105-12$.

Elves MW. The effect of $x$-irradiation upon the fate of cancellous bone allografts in inbred rats. Transplantation 1976; 22:31-6.

Elves MW, Lynette MP. The pattern of new bone formation in isografts of bone. Acta Orthop Scand 1975; $46: 549-60$.

Moore JB, Mazur JM, Zehr D, Davis PK, Zook EG. A biomechanical comparison of vascularized and conventional autogenous bone grafts. Plast Reconstr Surg 1984; 73-382-6.

Roy-Camille R, Laugier A, Ruyssen S, et al. The fate of cancellous bone grafts after irradiation. Rev Chir Orthop 1981; 67:599-608. (Eng. abstr.)

Weiland AJ. Current concepts review: vascularized free bone transplants. J Bone Joint Surg [Am] 1981 ; 63-A:166-9.

Weiland AJ, Phillips TW, Randolph MA. Bone grafts: a radiologic, histologic and biomechanical model comparing autografts, allografts, and free vascularized bone grafts. Plast Reconstr Surg 1984; 74:368-79. 